\title{
PERAN SERTA MASYARAKAT BANGKALAN DALAM MENGUSAHAKAN PENINGKATAN PEREKONOMIAN
}

\author{
Syukriyanti Muhktar \\ Muchammad Nurif*
}

\begin{abstract}
Abstrak
Banyak kalangan berpendapat bahwa kultur (sosial-budaya) suku Madura selama ini kurang menggembirakan. Karenanya, orang Madura sering dijadikan anekdot yang lucu-lucu, bahkan terkadang terkesan seram. Lalu bagaimana sebenarnya karakter etnis Madura ini? Padahal, karakter kultur unik orang Madura cukup positif, penuh semangat, dan tidak mudah menyerah. Karena masyarakat Madura juga terkenal dengan keuletan dan kegiginnnya. Khususnya dalam bidang peningkatan perekonomian.
\end{abstract}

Kata kunci : kultur, masyarakat, Madura, ekonomi

Menurut penelitian A. Latief Wiyata, dosen FISIP Universitas Jember, Madura memang memiliki karakteristik sosial budaya (sosbud) khas. Banyak hal tidak dapat disamakan dengan karakteristik sosbud masyarakat etnik lain. Sebuah realitas yang tidak perlu dipungkiri bahwa karakteristik sosbud Madura cenderung dilihat orang luar lebih pada sisi yang negatif.

Pandangan itu berangkat dari anggapan bahwa karakteristik (sikap dan perilaku) masyarakat Madura itu mudah tersinggung, gampang curiga pada orang lain, temperamental atau gampang marah, pendendam serta suka melakukan tindakan kekerasan. Bahkan, bila orang Madura dipermalukan, seketika itu juga ia akan menuntut balas atau menunggu kesempatan lain untuk melakukan tindakan balasan.

Semua itu, kata Latief, tidak lebih dari suatu gambaran stereotip belaka. Sebab, kenyataannya, salah satu karakteristik sosok Madura yang menonjol adalah karakter yang apa adanya. Artinya, sifat masyarakat etnik ini memang ekspresif, spontan, dan terbuka, tuturnya ketika menyampaikan makalah Lingkungan Sosial Budaya Madura dalam Seminar Prakarsa Masyarakat dalam Kerangka Pembangunan Daerah Madura di Universitas Bangkalan, beberapa waktu lalu.

\footnotetext{
* Dosen UPM Soshum ITS

jsh Jurnal Sosial Humaniora, Vol 4 No.1, Juni 2011 
Ekspresivitas, spontanitas, dan keterbukaan orang Madura, senantiasa termanifestasikan ketika harus merespon segala sesuatu yang dihadapi, khususnya terhadap perlakuan orang lain atas dirinya. Misalnya, jika perlakuan itu membuat hati senang, maka secara terus terang tanpa basa-basi, mereka akan mengungkapkan rasa terima kasihnya seketika itu juga. Tetapi sebaliknya, mereka akan spontan bereaksi keras bila perlakuan terhadap dirinya dianggap tidak adil dan menyakitkan hati.

Secara geografis, pulau Madura terletak pada $7^{\circ} \mathrm{LS}$ dan antara $112^{\circ}$ dan 114 BT (Wiyata, 2002:2009). Di pulau ini terdapat empat kabupaten yaitu Bangkalan, Sampang Pamekasan dan Sumenep. Pulau Madura dapat dikatakan sebagai pulau multietnik karena pulau ini tidak hanya didiami orang Madura saja, tapi juga didiami oleh orang Jawa, Sunda, Sumatera, Cina, dan Arab. Meskipun struktur masyarakatnya terdiri dari berbagai etnis, mayoritas dari populasi pulau ini adalah penutur asli bahasa Madura yaitu orang Madura dan bahasa komunikasi merekapun bahasa Madura (Azhar, 2008).

Tersebarnya masyarakat Madura di seluruh Indonesia menyebabkan bahasa Madura menjadi bahasa yang "tidak asing di Indonesia." Salain karena faktor interaksi penutur bahasa Madura dengan penutur bahasa lain, faktor media massa terutama film, sinetron dan lagu juga turut membantu proses pengenalan bahasa ini. Bintang film dan sinetron seperti Kadir, dan Buk Bariyah secara tidak sengaja, meskipun kadang tidak merepresentasikan bahasa Madura yang sesungguhnya, menjadi sosialisator bahasa Madura sehingga bahasa Madura menjadi lebih dikenal luas masyarakat Indonesia. Demikian juga lagu-lagu, telah turut serta mempromosikan bahasa Madura. Lirik lagu Ancor pessena tellor, yang dinyanyikan oleh Imam S. Arifin dengan genre musik dangdut pernah demikian terkenal sehingga banyak orang menjadi paham beberapa kosakata bahasa Madura. (Azhar, 2009), demikian juga lagu tradisional Tondu' Majeng yang sering dinyanyikan di even-even budaya turut pula mempromosikan bahasa Madura sebagai salah satu bahasa etnik Nusantara.

Madura, khususnya Bangkalan, memang mempunyai karakter kultur yang unik sebagaimana dijelaskan di atas. Selain itu, letak geografis yang cukup strategis 
tersebut juga memberikan banyak keuntungan.Salah satunya adalah dalam usaha peningkatan ekonomi di Madura.Apalagi setelah adanya jembatan Suramadu beberapa tahun lalu, perekonomian Bangkalan mulai meningkat pesat.Khususnya dalam hal bisnis.

Ketika melakukan bisnis, seorang pengusaha perlu melakukan perencanaan. Adapun perencanaan yang umumnya terkait adalah mengenai keputusan untuk memasuki dunia bisnis dan pengembangan bisnis yang ada.Ada beberapa hal dalam perencanaan bisnis, yaitu ide, kreatifitas, dan inovasi. Tanpa ketiga hal tersebut maka perencanaan bisnis yang dilakukan oleh pengusaha tidak akan lengkap dan mendalam.

\section{Pentingnya Inovasi, Ide, dan Kreativitas Bagi Pengusaha}

Ide pada dasarnya bukanlah hal yang mudah saya sampaikan terkadang dalam penyampaian ide haruslah didasari dengan cara komunikasi yang simple atau mudah dipahami. Ide di sini adalah hal yang dapat kita temukan dan kita cari untuk memecahkan suatu masalah yang kita temui. Sebagai contoh, untuk seorang engineer yang berkecimpung dalam bidang computer ide adalah suatu intisari yang harus kita miliki untuk memecahkan masalah yang ada pada suatu permasalahan yang ada pada suatu case tertentu dalam pembuatan program. Contoh lainnya adalah sebagai seorang pengusaha maka kita harus menemukan ide bagaimana cara untuk memanajemen karyawan, waktu, dan usaha apa yang kita pilih.

Adanya ide bukanlah hal mutlak untuk menentukan apakah suatu usaha yang kita jalankan dapat sukses atau tidak. Ada faktor lain yang menurut saya merupakan factor yang juga berpengaruh yaitu inovasi dan kreatifitas.

Inovasi adalah hal yang serupa atau mirip dengan kreativitas. Keduanya sama-sama membutuhkan ide untuk penerapannya.Mungkin perbedaan yang dapat saya sampaikan adalah inovasi adalah bentuk awal dari suatu kreatifitas, jadi inovasi adalah bentuk penerapan dasar dari ide yang kita miliki. Sebagai contoh inovasi yang dikembangkan dari kreatifitas adalah adanya jejaring sosial seperti facebook, twitter, skype yang membantu kita dalam berhubungan dan berkomunikasi dengan orang lain. 
Kreativitas bukanlah suatu hal yang dapat kita dapatkan dengan mudah ada kalanya kita harus meniru, mengamati dan mengembangkan dari orang lain dan juga dari alam. Sebagai contohnya dalam usaha penjualan makanan biasanya orang yang memiliki kr eatifitas yang lebih akan memiliki produk yang berbeda dari biasanya, entah itu rasa atau bentuknya. Contoh lain yang dapat saya ambil adalah para ilmuwan yang serng mengamati kejadian yang ada di alam sehingga para ilmuwan tersebut dapat menciptakan alat-alat baru, sebagai contoh sederhana pembuatan pesawat terbang tentunya sebagai pembaca anda tentunya sudah dapat mengira-ngira apa yang ilmuwan tiru sebagai ide kreatif dari rancangan bentuk pesawat tersebut? Ya Benar burung, pesawat memiliki sayap dan aerodinamika yang hamper sama dengan burung. Selain itu para ilmuwan juga mengamati alam untuk menemukan ide-ide kreatif dalam mengatasi dan menanggulangi bencana alam, seperti contohnya alat pendeteksi tsunami. Alat tersebut tercipta karena adanya ide dan kreatifitas yang muncul karena adanya rasa prihatin akan banyaknya bencana alam yang melanda dunia. Kreatifitas bukan hanya digunakan untuk untuk menciptakan suatu usaha yang menarik dan ber-profit besar. Kreatifitas juga merupakan dasar dari penemuan suatu rumus dalam ilmu-ilmu alam seperti dalam rumus newton dan juga rumus-rumus ilmiah lainnya yang membingungkan dan saling membutuhkan satu sama lainnya.

Hal-hal diatas sekiranya cukup membantu pembaca untuk memahami apa itu ide kreatifitas dan inovasi. Jadi kesimpulan yang dapat saya sampaikan disini adalah ide adalah hal pertama yang harus kita dapatkan dengan cara menggali dalam pikiran kita untuk menciptakan suatu kreatifitas dan inovasi.

1. Inovasi Berbisnis

Ketika mendengar kata inovasi, yang muncul di benak kita barang kali ssesuatu yang bersifat baru, unik, dan menarik. Pengertian inovasi menurut beberapa ahli antara lain:

a) Menurut Essentad inovasi adalah proses perubahan sosial, ekonomi politik, yang telah berkembang di Eropa Barat dan Amemrika utara dari abad ke 1719 dan kemudian berkembang pula ke Amerika Selatan, Asia dan Amerika. 
b) Menurut Zalman dan Ducan inovasi adalah perubahan sosial yang digunakan untuk mencapai tujuan tertentu dan diamati sebagai suatu yang baru bagi sekelompok orang. Tetapi perubahan sosial belum tentu inovasi.

c) Inovasi adalah gagasan, perbuatan atau sesuatu yang baru dalam konteks sosial tertentu dan pada suatu jangka waktu tertentu untuk menjawab masalah yang dihadapi. Sesuatu yang baru, mungkin sudah lama dikenal pada konteks sosial lain untuk sesuatu itu sudah lama dikenal tetapi belum dilakukan perubahan. Dapat disimpulkan bahwa inovasi adalah perubahan, tetapi semua perubahan belum tentu inovasi (Mohd.Ansyar dan H. Nurtain, "Pengembangan dan Inovasi Kurikulum". 1991:30).

Kata inovatif berasal dari bahas inggris "innovate" yang artinya memperkenalkan sesuatu yang baru sedangklan innovative berarti bersifat memperbarui. Kemudian kata "innovate" dan "innovative" yang merupakan bahasa Indonesia dengan mengalami perubahan penulisan menjadi "inovatif" yang berarti bersifat memperkenalkan suatu yang baru. Sedangkan orang yang melakukan pembaharuan disebut "innovator".

Ciri manusia inovatif:

1. Gila belajar dan bekerja

2. Selalu berorientasi kedepan

3. Kaya ide-ide yang cemerlang

4. Berfikir rasional dan berprasangka baik

5. Menghargai waktu dan menggunakannya dengan sebaik-baiknya

6. Suka melakukan eksperimen

2. Ide

Ide berarti gagasan. Dalam Kamus Besar Bahasa Indonesia (KBBI), ide adalah rancangan yang tersusun di pikiran. Artinya sama dengan gagasan atau citacita. Ide dalam kajian Filsafat Yunani maupun Filsafat Islam menyangkut suatu gambaran imajinal utuh yang melintas cepat. Misalnya: idetentang sendok, muncul dalam bentuk sendok yang utuh di pikiran. Selama ide belum dituangkan menjadi 
sebuah konsep dengan tulisan maupun gambar yang nyata, maka ide masih berada di dalam pikiran.

Ide yang sudah dinyatakan menjadi suatu perbuatan adalah karya cipta. Untuk mengubah ide menjadi karya cipta dilakukan serangkaian proses berfikir yang logis dan seringkali realisasinya memerlukan usaha yang terus menerus sehingga antara ide awal yang muncul di pikiran dan karya cipta satu sama lain saling bersesuaian sebagai kenyataan. Alam Pikiran Yunani menjangkau pengertian Ide Ideal atau Ide Sempurna.Dari pemikiran tentang yang smepurna itu lahirlah gagasan-gagasan tentang kebutuhan ketuhanan sebgai Ide Ideal Tertinggi yang dapat dipikirkan dan dirasakan oleh manusia keberadaannya yaitu tentang Pencipta Mahluk atau Tuhan.

Tokoh utama dari Alam Semesta Yunani yang membahas tentang ide dan pikiran sebagai kajian filsafat adalah Plato.Ajaran tentang ide merupakan init dan dasar seluruh filsafat Plato.'Ide' yang dimaksud oleh Plato disini berbeda dengan pengertian ide yang sekarang.Dalam bahasan-bahasan modern, 'ide' berarti suatu gagasan atau tanggapan yang hanya terdapat dalam pemikiransaja. Akibatnya $=$, bagi orang modern ide merupakan sesuatu yang bersifat subjektif belaka.

'Ide' menurut Plato sangat berbeda dengan $\mathrm{p}$ [enegrtian ide yang telah disebutkan diatas. Bagi Plato, ide merupakan sesuatu yang obvjektif. Ide-ide tidak diciptakan dan tidak tergantung pada pemikiran.Sebaliknya pemikiran tergantung pada ide-ide.Justru karena ide berdiri sendiri, pemikiran itu dimungkinkan. Pemikirab itu tidak lain daripada menaruh perhatian kepada ide-ide itu. Plato juga sangat dipengaruhi oleh kaum Phytagorean dalam teori tentang ide-nya itu. Untuk lebih memaha,i teori 'ide' berikut penulis mencoba memberikan gambaran melalui contoh. Misalkan saja, ada banyak hal yang boleh disebut 'bagus"' : kain bagus, patung bagus, rumah bagus, dsb. Sehelai kain tidak disebut bagus karena itu kain, sebabg ada juga kain yang jelek.Yang menyebabkan kain itu disebut bagus adalah ide 'yang bagus'. Karena itu, ide "yang bagus" merupakan 'yang bagus" itu sendiri, secara sempu; tidak tercampur dengan sesuatu yang lain. Plato menyebutnya dengan kata Yunani idea atau eidos.

2. Kreativitas 
Pengertian kreativitas sudah banyak dikemukakan oleh para ahli berdasarkan pandangan yang berbeda-beda, seperti yang dikemukakan oleh Utamu Munandar (1992:47) menjelaskan pengertian kreativitas dengan mengemukakan bebrapa perumusan yang merupakan kesimpulan para ahli mengenai kreativitas.Pertama kreativitas adalah kemampuan untuk membuat kombinasi baru berdasarkan data, informasi, atau unsur-unsur yang ada. Kedua, kreativitas (berfikir kreatif atau berpikir divergen) adalah kemampuan berdasarkan data atau informasi yang tersedia, menemukan banyak kemungkinan jawaban (Utami Munandar, 1992 :48). Ketiga secara operasional kreativitas dapat dirumuskan sebagai kemampuan yang mencerminkan kelancarab, keluwesab (fleksibilitas dan orisinalita dalam berpikir, serta kemmapuan untuk mengelaborasi (mengembangkan, memeperkaya, merinci) suatu gagasan.

Slameto $(2003 ; 145)$ menjelaskan bahwa pengertian kreativitas berhubungan dengan penemuan sesuatu, mengenai hal yang menghasilkan sesuatu yang baru dengan menggunakan sesuatu yang telah tidak ada.Sesuatu yang baru itu mungkin berupa perbuatan atau tingkah laku, bangunan, dan lain-lain. Menurut Moreno dalam Slameto $(2003 ; 146)$ yang penting dalam kreativitas itu bukanlah penemuan sesuatu yang belum pernah diketahui oleh orang sebelumnya, melankan bahwa produk kreativitas itu merupakan sesuatu yang baru bagi diri sendiri dan tidak harus merupakan sesautu yang baru bagi orang lain atau dunia pada umumnya, misalnya seorang guru menciptakan metode mengajar dengan diskusi yang belum pernah ia pakai.

Menurut Cece Wijaya dan Tabrabi Rusyan (1991:189), kreativitas biasabya siartikan sebagai kemampuan untuk menciptakan suatu produk baru, baik yang benar-benar baru sama sekali maupun yang merupakan modifikasi atau perubahan dengan mengembangkan hal-hal yang sudah ada.

Menurut pendapat Sund dalam Slameto (2003:147-148) menyatakan bahwa individu dengan potensi kreatif dapat dikenal melalui pengamatan ciri-ciri sebagai berikut:

a) Hasrat keingintahuan yang cukup besar

b) Bersikap terbuka terhadap pengalaman baru 
c) Panjang akal

d) Keingintahuan untuk menemukan dan meneliti

e) Cenderung lebih menyukai tugas yang berat dan sulit

f) Cenderung mencari jawaban yang luas dan memuaskan

g) Memiliki dedikasi bergairah serta aktif dalam melaksanakan tuga

h) Berfikir fleksibel

i) Menanggapi pertanyaan yang diajukan serta cenderung memberi jawaban lebih bayak

j) Kemampuan membuat analis dan sitesis

k) Memiliki semangay bertanya serta meneliti

1) Memiliki daya abstraksi yang cukup baik

m) Memiliki latar belakang membaca yang cukup luas

\section{Peran Sarta Masyarakat}

1. Suramadu, Sang Penggerak Perekonomian Madura

Jembatan Suramadu adalah jembatan yang melintasi Selat Madura, yang menghubungkan pulau Jawa (di Surabaya) dan pulau Madura (di Bangkalan) dengan panjang mencapai $5.438 \mathrm{~m}$. Jembatan Suramadu diresmikan awal pembangunannya oleh Presiden Megawati Soekarnoputri pada 20 Agustus 2003 dan diresmikan pembukaannya oleh Presiden Susilo Bambang Yudhoyono pada 10 Juni 2009. Dana yang dibutuhkan untuk membangun jembatan suramadu sebesar 4,5 trilyun yang dibiayai dari APBN dan pinjaman luar negeri. Pembangunan jembatan suramadu ditujukan untuk mempercepat pembangunan di pulau Madura, yang meliputi bidang infrastruktur dan ekonomi di Madura, yang relatif tertinggal dibandingkan kawasan lain di Jawa Timur.

Setelah beroperasi lebih dari 1 tahun jembatan suramadu memberikan dampak langsung bagi perkonomian di Bangkalan.aKtivitas ekonomi di Bangkalan atas besarnya jumlah uang yang dibelanjakan oleh wisatawan yang hanya sekedar ingin tau jembatan suramadu.

2. Bebek Sinjay Madura 
Nasi bebek Sinjay di Bangkalan Madura yang terkenal kelezatannya.Kirakira 10 menit dari pintu exit Tol di sisi Madura, kami sudah sampai di Warung Nasi Bebek Sinjay.Warung berukuran 4x2 meter persegi itu beralamat di Jalan Raya Ketengan no. 45 Tunjung Bumeh Bangkalan.Banyak mobil dan motor yang parkir. Padahal, waktu belum menunjukkan pukul 09.00 pagi.Warung tersebut cukup luas, sehingga bisa banyak menampung pengunjung.

Menurut sumber yang memiliki minimal setiap hari menghabiskan 800 ekor bebek. Ini tidak termasuk didalam suasana hari libur Yang membuatnya tambah nikmat adalah sambalnya mempunyai ciri khas yang rasanya asam-asam pedas, terbuat dari mangga muda (pencit).

3. Pasarehan KH. A.Chalil

Komplek Pesarean K.H. A. Cholil setelah kenyang dengan kenikmatan Bebek Sinjay. Desa Mertajasah Kecamatan Bangkalan disitulah pesarean / maqam Syaichona cholil gurunya para kiai besar yang ada di Madura dan Jawa. Masjid syaichona kholil nampak megah, bangunan lama direnovasi nampak dari kejauhan kemegahan masjid di kompleks pesarean.

A. Cholil bin Abdul Latif atau terkenal dengan sebutan Syaichona Cholil. $1235 \mathrm{H}-1343 \mathrm{H}$, Syaichona Cholil ikut berperan penentu dari berdirinya organisasi terbesar di Indonesia yakni Nahdlatul Ulama (NU), maqam syaichona cholil merupakan salah satu tujuan wisata religi khususnya para santri dan umat islam di pulau madura dan jawa.

Syekh Cholil banyak meninggalkan "warisan" yang bermanfaat untuk ummat. Diantaranya adalah sebagai berikut:

a) Pesantren Jangkibuan. Pesantren ini terus aktif sampai kini dan diasuh oleh keturunan Nyai Khotimah bin Cholil dengan Kiai Thoha. Pesantren ini diberi nama "Pesantren Al-Muntaha Al-Kholili".

b) Pesantren Kademangan. Sepeninggal Syekh Cholil, pesantren ini diasuh oleh keturunan beliau sendiri.

c) Kitab “As-Silah fi Bayanin-nikah". Sebuah kitab tentang pernikahan, meliputi segi hukum dan adab. Dicetak oleh Maktabah Nabhan bin Salim Surabaya. 
d) Rangkaian Shalawat. Dihimpun oleh KH. Muhammad Cholid dalam kitab "I'anatur Roqibin" dan dicetak oleh Pesantren Roudlotul Ulum, Sumber Wringin, Jember. Jawa Timur.

e) Dzikir dan wirid. Dihimpun oleh KH. Mushthofa Bisri, Rembang, Jawa Tengah, dalam sebuah kitab berjudul "Al-Haqibah".

\section{Manfaat Bagi Masyarakat Sekitar}

Takmir pasarean KH A..Cholil menyebutkan bahwa sejak jembatan suramadu beroperasi maka paling tidak ada 100 - 200 rombongan yang masingmasing rombongannya terdiri dari 30-50 peziarah yang datang tiap minggunya.

Banyaknya peziarah yang berkunjung ke pasarean KH A..Cholil disebabkan karena akses yang mudah dan murah saat menuju Bangkalan selain juga disebabkan untuk merasakan melintas di atas jembatan suramadu seperti yang diakui oleh Abdurrahman salah seorang peziarah.Dampaknya adalah aktivitas ekonomi di sekitar pasarean KH A.Cholil yang semakin meningkat.

4. Batik Tulis Madura

Bangkalan adalah salah satu sentra batik Madura yang terkenal dengan nama batik tanjungbumi. Sejak jembatan suramadu beroperasi, keadaan pedagang dan pengrajin batik tanjungbumi berubah dengan drastis.Bisa dilihat dari kisah sukses galeri batik Tresna Art, Bangkalan.

Supik, pemilik galeri Tresna Art di Bangkalan, mengatakan bahwa omzet penjualan batik yang ada di toko miliknya meningkat hingga 3 kali dibandingkan sebelum jembatan suramadu beroperasi.Ia bahkan mampu menjual 500 potong pada akhir pekan dengan keuntungan hingga 3 juta. Keuntungan serupa juga diperoleh para pemilik galeri batik di Bangkalan sehingga saat ini makin banyak dijumpai galeri batik di kota Bangkalan. Besarnya permintaan batik di pedagang batik berimbas pada pengrajin.Menurut data dari Dinas Koperasi dan UMKM Kabupaten Bangkalan, jumlah pengrajin batik tanjungbumi mencapai 1000 orang. Saat ini, para pengrajin tidak mampu untuk memenuhi permintaan batik sehingga untuk mengatasinya pengrajin mulai melakukan inovasi dengan memunculkan batik cap dan batik printing. Sebagai perbandingan, 1 batik tulis membutuhkan waktu 15 hari 
untuk memproduksinya sedangkan batik cap dalam satu hari dapat diproduksi 50 batik dan batik printing dalam satu hari dapat diproduksi hingga 500 batik.

Ilmu batik turun temurun diajarkan kepada para perajin batik.Jumlah perajin batik di galeri mencapai 100 orang dengan pengerjaan batik tulis paling cepat adalah 2 bulan dan paling lama adalah 6 bulan. Proses batik meliputi penggambaran, pengisian, penebalan, pewarnaan dilakukan dalam 8 proses. Sedangkan Kendala dalam produksi batik tulis adalah sinar matahari yang tidak menentu karena cuaca yg tidak mendukung, padahal Madura terkenal dengan cuacanya yang panas.

Ciri khas batik Madura adalah menggambarkan makhluk-makhluk hidup dan alam-alam yang natural.Pola batik tidak ditentukan namun dibebaskan pada perajin untuk membuat gambar batik sesuai hati mereka.

\section{Kesimpulan}

Kultur (sosial-budaya) suku Bangkalan, Madura memang tergolong unik. Sebagian orang menganggapnya negatif, tapi tidak banyak yang berpendapat hal itu adalah nilai positif yang patut dibanggakan.Padahal, karakter orang Madura yang penuh semangat, tidak mudah menyerah, serta ulet dan gigih.Selain itu, ekspresivitas, spontanitas, dan keterbukaan orang Madura, senantiasa termanifestasikan ketika harus merespon segala sesuatu yang menarik bagi mereka.

Madura, khususnya Bangkalan, memang mempunyai karakter kultur yang unik sebagaimana dijelaskan di atas. Selain itu, letak geografis yang cukup strategis tersebut juga memberikan banyak keuntungan.Salah satunya adalah dalam usaha peningkatan ekonomi di Madura.Apalagi setelah adanya jembatan Suramadu beberapa tahun lalu, perekonomian Bangkalan mulai meningkat pesat.Khususnya dalam hal bisnis.

Tak dapat dipungkiri, kreativitas masyarakat Bangkalan memang mampu meningkatkan usaha di bidang ekonomi daerah Madura.Hal ini bisa dilihat pada pertumbuhan usaha-usaha ekonomi di sekitarnya.Mulai dari penjual-penjual souvenir di sekitar Jembatan Suramadu, rumah makan bebek sinjay, usaha batik tulis khas Madura, dan masih banyak lagi yang lainnya. 
Dapat disimpulkan bahwa pertumbuhan ekonomi di sekitar Bangkalan, Madura, salah satunya adalah berkat pertumbuhan usaha-usaha kecil dan lancarnya distribusi serta transportasi sejak adanya jembatan Suramadu.Lambat laun kondisi ekonominya pun maju pesat.Dan hal ini merupakan salah satu peluang emas untuk peningkatan ekonomi Indonesia timur, khususnya Madura.

\section{Daftar Pustaka}

Achmadi, asmoro. 1997. Filsafat umum. Jakarta: PT. Raja Grafindo

Bean, Reynold. Cara mengembangkan kreativitas anak. Alih bahasa: Dra. Med Meitasari Tjandrasa. Jakarta: Binarupa Aksara. 1995

Bertens, K. 1999. Sejarah Filsafat Yunani. Yogyakarta: Penerbit Kanisius

Busthom, A. 2007. Memancing Kreativitas. Jakarta: Penerbit Multiply

Direxion Consulting. 2006. Direxion Newsletter. Bandung: Direxion Strategy Consulting

Hartono. 2004. Kreatif dalam Berbisnis. Bandung: Empat Lima

Helmi, S. 2006. Buku Ajar Studi Kelayakan Bisnis. Sumatera Utara: Universitas Sumatera Utara

Khoiriah, NE. 2006. Variasi Seni Rupa dalam Pembelajaran Anak Usia Dini. Semarang : Universitas Negeri Semarang

Nurlaelah, E. 2003.Formasi Kreativitas dalam Pendidikan Matematika. Jakarta: Universitas Pendidikan Indonesia

Saidi, Anwar. 1994. Menjadi Wirausaha Sukses. Jakarta : Pustaka Jaya

Toffler, A. 1980.The Third Wave. Cincinnati: Shouth western Publishing Co Ohio

"Karakter Etnis Madura dan Kebiasaan Carok" dalam http://kabarmadura07.blogspot.com/2008/08/kebiasaan-carok.html, diakses pada 11 September 2011

"Karakter Masyarakat Madura Dalam Syair-syair Lagu Daerah Madura" dalam http://pusatbahasaalazhar.wordpress.com/artikel-sastra/karakter-masyarakatmadura-dalam-syair-syair-lagu-daerah-madura/, diakses pada 11 September 2011 